\title{
Expression of recombinant proteins in insect and mammalian cells
}

DOI:

10.1016/j.ymeth.2018.05.013

\section{Document Version}

Accepted author manuscript

Link to publication record in Manchester Research Explorer

\section{Citation for published version (APA):}

Mckenzie, E., \& Abbott, WM. (2018). Expression of recombinant proteins in insect and mammalian cells. Methods, 40. [147]. https://doi.org/10.1016/j.ymeth.2018.05.013

\section{Published in:}

Methods

\section{Citing this paper}

Please note that where the full-text provided on Manchester Research Explorer is the Author Accepted Manuscript or Proof version this may differ from the final Published version. If citing, it is advised that you check and use the publisher's definitive version.

\section{General rights}

Copyright and moral rights for the publications made accessible in the Research Explorer are retained by the authors and/or other copyright owners and it is a condition of accessing publications that users recognise and abide by the legal requirements associated with these rights.

\section{Takedown policy}

If you believe that this document breaches copyright please refer to the University of Manchester's Takedown Procedures [http://man.ac.uk/04Y6Bo] or contact uml.scholarlycommunications@manchester.ac.uk providing relevant details, so we can investigate your claim.

\section{OPEN ACCESS}




\section{Manuscript Details}

Manuscript number

Title

Article type
METHODS_2017_241_R1

Expression of recombinant proteins in insect and mammalian cells

Review Article

\section{Abstract}

Purified recombinant proteins are key reagents in academic and industrial research. The ability to make these proteins quickly often relies on the availability of higher eukaryotic cell hosts such as insect and mammalian cells where there is a very wide range of post-translational modifications, protein folding and trafficking pathways. This enables the generation of many proteins that cannot be made in microbial hosts. In this article we outline some of the most commonly used methods to express recombinant proteins in insect and mammalian cells.

Keywords

Corresponding Author

Corresponding Author's Institution

Order of Authors

Suggested reviewers baculovirus insect cells; mammalian cells; transient transfection

Mark Abbott

Peak Proteins Ltd

Mark Abbott, Edward McKenzie

Ian Hunt, Stephen Prince, Raymond Owens, Imre Berger, Robert Boyd

\section{Submission Files Included in this PDF}

\section{File Name [File Type]}

covering letter May 2018.docx [Cover Letter]

Response to Reviewers.docx [Response to Reviewers]

Highlights.docx [Highlights]

revised Manuscript.docx [Manuscript File]

Figs 4th May 2018.pptx [Figure]

To view all the submission files, including those not included in the PDF, click on the manuscript title on your EVISE Homepage, then click 'Download zip file'.

\section{Research Data Related to this Submission}

There are no linked research data sets for this submission. The following reason is given:

The authors do not have permission to share data 


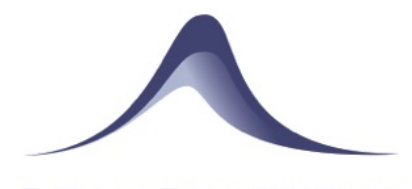

PEAK PROTEINS

Dr W. Mark Abbott

Peak Proteins Ltd.

3G48, BioHub,

Mereside, Alderley Park

Cheshire

SK10 4TG

UK

$10^{\text {th }}$ May 2018

Dear Sir/Madam,

I enclose the files to resubmit a review in the journal Methods entitled Expression of recombinant proteins in insect and mammalian cells. I look forward to hearing from you

Yours sincerely

Mark Abbott PhD 


\section{$\underline{\text { Response to Reviewers }}$}

We are grateful for the helpful comments of the reviewers to help us improve the article. Our responses are described below.

\section{Reviewer 1}

- We have now included more examples of the use of both baculovirus/insect cell and mammalian systems. We have also included a Table and additional text comparing the two systems from both a scientific and pragmatic/cost perspective.

- Figure 1 has been redrawn

- The study by Zhao et al (2003) has now been included

- Figure 3 and legend has been altered as requested

- More information has now been included on protein names. Where possible this has been the exact name (TIMP2) but in other cases confidentiality agreements mean we have had to use a generic term e.g. Ig domain containing protein. The method used to quantify yield is now described.

\section{Reviewer 2}

- The workflow for transient expression is now described in the text. We chose to do so rather than drawing a figure as the process is very simple.

- We have now referenced and discussed the baculovirus benchmarking study reported by Stolt-Bergner et al (2018) 
- Higher eukaryotic expression systems are often the preferred choice for complex proteins requiring post translational modification including folding.

- The most frequently used systems are baculovirus infected insect cells and HEK or CHO mammalian cells.

- Despite their obvious advantage over microbial hosts there are often still problematic proteins that require significant effort to overcome the difficulties.

- Membrane proteins perhaps represent the greatest challenge but significant progress has been made to devise methods to express, purify and then use these membrane proteins to facilitate structural biology and approaches to discover new therapeutic agents. 


\title{
Title - Expression of recombinant proteins in insect and mammalian cells
}

\author{
Edward A McKenzie ${ }^{1}$ and W Mark Abbott ${ }^{2}$ \\ 1 Protein Expression Facility, Manchester Institute of Biotechnology, Faculty of Life \\ Sciences, 131 Princess Street, Manchester, M1 7DN, UK \\ 2 Peak Proteins Ltd, Alderley Park, Cheshire, SK10 4TG, UK
}

\begin{abstract}
Purified recombinant proteins are key reagents in academic and industrial research. The ability to make these proteins quickly often relies on the availability of higher eukaryotic cell hosts such as insect and mammalian cells where there is a very wide range of post-translational modifications, protein folding and trafficking pathways. This enables the generation of many proteins that cannot be made in microbial hosts. In this article we outline some of the most commonly used methods to express recombinant proteins in insect and mammalian cells.
\end{abstract}

\section{General Introduction}

Recombinant protein technologies underpin not only much research but also the manufacture of biological drugs. The focus of this review is on the provision of protein reagents when generally only small quantities are required (tens of micrograms to a few hundred milligrams). However laboratories that undertake this type of work will frequently need to produce many different types of protein and in a timescale measured in weeks.

The first choice to express any protein if it can be achieved would always be a microbial host in particular E.coli as the cells are easy, fast and cheap to culture. However post translational modifications are very limited and many proteins are expressed in an insoluble, unfolded form even when a variety of different approaches are investigated such as alternative strains, reduced temperature and co-expression of chaperones. As a consequence, higher eukaryotic hosts are frequently used, the two most common being baculovirus infected insect cells and various different mammalian cell hosts, most commonly $\mathrm{CHO}$ and HEK cells. A further key consideration with regard to membrane proteins is the lipid composition of the membrane which can be critical for the function of the protein. Thus for example E.coli do not contain sterols whereas mammalian cells contain cholesterol and insect cells and yeast ergosterol). Both insect and mammalian systems are used most simply when the cells are maintained in suspension culture in protein free medium. Culturing cells in suspension enables a much greater cell density to be achieved and therefore higher expression per volume of cell culture medium. The use of protein free medium greatly facilitates purification if the protein is secreted.

In this article we describe the different approaches that are used to generate recombinant baculoviruses and then the methods to use those viruses to enable protein expression in different insect cell lines. The methods that we will describe to express recombinant proteins in mammalian cells primarily use transient transfection rather than the generation of stable cell lines due to the short timelines that are generally needed for this type of work. 
Methods for baculovirus insect cells - from dark horse to biotech work horse.

\section{Introduction}

The Insect Cell Baculovirus Expression Vector System (BEVS) was first developed in 1983 by Smith, Summers and Fraser [1] in their landmark publication on the production of IFN- $\square$ protein. The IFN- $\square$ gene was inserted into the polyhedrin gene locus and active protein successfully secreted from SF21-AE cells. The early days of baculovirus research where it was viewed as a dark horse with unknown potential [2] have long gone. Instead an expanding range of baculovirus transfer plasmids and modified viral genomes encoding networks of genes have now been created to specifically boost recombinant protein production, stability and solubility. The overall system is depicted in Figure 1.

\section{Growth \& maintenance of insect cells}

Sf9, Sf21 and High Five cells are grown between $26-29^{\circ} \mathrm{C}$ in adherent cultures in humidified incubators without $\mathrm{CO}_{2}$ or in suspension shake flasks. Baculoviruses are light sensitive and so should be kept in the dark at $4{ }^{\circ} \mathrm{C}$ with the addition of $2 \%$ FBS to help maintain virus stability. They can be stable for up to one year but this can be variable depending on the recombinant gene insert size [3]. It is highly recommended that new batches of media be tested for infectivity and protein production as anecdotal experience from the insect cell community shows this to be problematic.

\section{Methods to determine virus titres}

The classical method to determine the titre of a virus is by plaque assay. A monolayer of cells (usually Sf9) are infected with various dilutions of virus and then overlaid with low melting point agarose. After 1 week the virally infected cell plaques against the uninfected cell background are stained with neutral red and the particle forming units (pfu) per ml calculated. A more rapid and accurate method can be carried out using qPCR against the specific viral envelope glycoprotein gene GP64. The GP64 protein appears on the surface of virally infected cells around 6hrs post infection and can be detected by flow cytometry with a fluorescently coupled anti GP64 antibody. A range of alternative approaches with faster turn-around times and higher accuracy have been previously described in detail [4].

\section{Lepidopteran Insect Cell Lines-original and engineered}

The most commonly used insect cell lines in research are Sf9 and Sf21cells both derived from the Spodoptera frugiperda fall army worm pupal ovary and High Five derived from the Trichoplusia ni cabbage looper embryo. Surprisingly there are over 100 original cell lines described which are capable of being infected with the Autographa Californica Multiple Nucleopoly-hedrovirus (AcMNV) and yet these have not been fully characterised. The cell line Ao38, isolated from eggs of the black witch moth was shown to be permissive for AcMNPV infection. It produced $1.5 \mathrm{x}$ more recombinant protein compared to regular High Five cells and the cells were also easily adaptable to serum free suspension growth [5]. Further analysis of the Ao38 
cell line however showed that it was most likely a clonal derivative of the High Five Tn-5B1-4 cell line.

To try and overcome the limitation of the simple mannose glycosylation repertoire of insect cells, the SfSWT-5 cell line was created which contains 6 key glycogenes (produced by 3 dual piggyback vectors) under a doxycycline inducible promoter. This cell line was shown to be highly stable over 300 passages, had equivalent total expression compared to $\mathrm{Sf} 9$ cells and was capable of producing fully sialyated proteins [6].

\section{Insect cell promoters and stage specific activation -when to express your protein?}

The infection of insect cells with baculoviruses follows four defined stages (Figure 2). During the Immediate Phase (0-4hrs PI) viruses are transported into the cell and viral DNA is released into the nucleus. This is followed by the Early Phase (4-7hrs PI) when baculovirus DNA replication occurs. During the Late Phase (7-24hrs PI) budded baculoviruses are released and secondary infection occurs. During the Very Late Phase (24hrs until cell death) the stage specific promoters become active and occluded viruses accumulate in the cell nucleus [7]. Traditionally the strong very late phase promoters, polyhedrin (polh) and P10 are used since they produce the highest levels of recombinant protein. It is recommended that earlier promoter based plasmids are included in new protein expression trials however, as this may result in improved glycosylation, solubility and overall yields. Recently the stronger orf $46120 \mathrm{bp}$ promoter region was characterised and demonstrated to have a two-fold activity increase over polh alone and to act additively when used in combination with polh [8].

\section{Baculovirus transfer plasmids}

A large number of commercial baculovirus transfer plasmids are available and these have been comprehensively compiled [9, 10]. The pVL1393 plasmid provides essentially a blank canvas backbone for single untagged protein expression. The dual expression plasmid pACUW51 drives independent protein expression from the P10 and polh promoters. Multiple protein subunits or higher protein complexes can be expressed in the pBac4x vector. For active secretion into the media, vectors containing the GP67 signal peptide leader have been produced. Generally, affinity tags are added at the C-terminus of proteins destined for secretion to help prevent mis-sorting or interference with signal peptide trafficking. Simple N or C terminal Hexahistidine tags are the most commonly used for easy to express recombinant expression in insect cells but derivatives with additional affinity/solubility tags have been produced (eg His-GST, His-NusA, His-Thioredoxin). The OET vector collection is continually being expanded and of particular note is the latest pOET8 plasmid that contains the P-vank-1 vankyrin gene driven by the late p10 promoter. Vankryin is an anti-apoptotic protein that delays apoptosis and so can extend the period of protein production and may be beneficial for proteins requiring post-translational modifications (eg glycosylation) [11]. The pBacSurf vector contains the GP64 gene leader to send protein fusions to the virus particle surface and this has allowed direct structural analysis by electron microscopy [12] and monoclonal antibody development [13]. The BacMam vector series contains the gene of interest under the control of the CMV promoter to permit virus transduction of mammalian cells. 


\section{Generating recombinant viruses}

\section{flashBAC ${ }^{\mathrm{TM}}$}

The flashBAC ${ }^{\mathrm{TM}}$ method developed by Oxford Expression Technologies [14] involves co-transfecting insect cells with viral DNA along with the transfer plasmid containing the gene of interest. Reconstitution then takes place within the Sf9 cell by homologous recombination. An essential gene (ORF1629) has been deleted from the viral genome and triple digested with restriction enzymes to prevent non recombinant viable viruses being produced. New generations of flashBAC have been generated to increase the yield and stability of recombinant proteins by deleting the cathepsin like cysteine protease V-Cath (flashBAC gold). Three additional genes encoding the P10, P74 and P36 proteins have also been deleted to further increase protein yield (flashBAC Ultra). A viral DNA designed specifically to improve the production of VLPs has also been produced (flashBAC prime). A similar homologous recombination method based around the targeted viral gene knockout of the essential ORF1629 and its subsequent complementation by a transfer plasmid has also been described by Zhao et al [15].

\section{Bac-to-Bac}

The Bac-to-bac method marketed by ThermoFisher Scientific [16] is based on the site specific transposition of an expression donor plasmid with a bacmid shuttle vector in E.coli. The donor plasmid contains gene flanking Tn7 sites that allow direct transposition into the Bacmid att Tn7 site. The E.coli strain DH10 Bac contains the helper plasmid pMON 7124 that encodes for the transposase enzyme. The high molecular weight recombinant DNA produced is purified and then transfected into insect cells to produce the recombinant virus. A second generation of the $\operatorname{Tn} 7$ based system called Bac-2-the-future uses modified vectors and E.coli helper strains to increase the transposition efficiency, eliminate false positives so reducing costs [17].

\section{MultiBac}

In this method multigene cassettes are first created by tandem recombineering and Cre Lox site specific recombination and then inserted into the MultiBac genome by Tn7 transposition [18]. The MultiBac systems are all commercially available through Geneva Biotech [19]. Similar to the flashBAC viral DNA, the V-Cath protease and Chi A genes have also been inactivated in the MultiBac genome. A YFP gene is encoded in the genome to allow real time monitoring of viral performance and also to help optimise the optimal expression harvest time [20].

\section{Synthetic Viral Nanosystems- evolution of MultiBac}

The glycosylation gene $\mathrm{N}$-acetylglucosaminyl transferase II under the polh promoter and the bovine $\square$ 1,4-galactoysl transferase I gene under the $p 10$ promoter were inserted into the Loxp site of the MultiBac genome to create the Sweet Bac genome capable of producing more complex sugars such as those found in mammalian cells [21]. A kinase factory SVN containing seven chaperones (Hop, Hsp40, P23, PPID, AHSA1, CDC37 and HSPA5) integrated at the Loxp site was shown to significantly 
improve both the expression and solubility of various test kinases studied. MultiBacMam containing a VSV-G gene has been reported to enhance transduction efficiency and has considerable potential for introducing genes into primary cells. Cas9 and the necessary guide RNA machinery have now been inserted to create a viral delivery system capable of genome engineering [20].

\section{Synthetic Baculovirus}

The creation of the first synthetic AcMNPV baculovirus opens up the exciting potential to create a 'mini-baculovirus' to identify the minimum replicative/infection units required for virus survival and importantly creating extra genome space for future genetic engineering modifications. Scanning electron microscopy confirmed that the viral occlusion bodies were formed correctly [22].

\section{Transient non-viral system- Insect Cell Direct}

A simple method to generate small amounts of recombinant protein in insect cells can be achieved by transient transfection of expression plasmids (pIEx series) containing the genes of interest driven by the immediate early iel promoter. An additional enhancer element $h r 5$ boosts transcription and allows recombinant protein to be produced within 48 hours post transfection [23].

\section{Drosophila S2 stable cell system}

The Drosophila Expression System (DES) involves generating stable cells in Schneider 2 (S2) cells with the selection plasmid carrying the gene of interest. Both inducible and constitutive vectors are commercially available. Higher copy integrants can be generated by altering the ratio of expression plasmid to the antibiotic selection agent. Stably transfected S2 cells can be grown to high concentrations in suspension cultures which allows for scaling up and maximising protein yield. The system is most often used for secreted proteins and is reviewed in greater detail elsewhere [24].

\section{Benchmarking study on baculovirus driven expression technologies}

A recent benchmarking study has been published of 15 different laboratories in the Protein Production and Purification Partnership in Europe (P4EU) network [25]. The 15 laboratories were asked to express the same 4 "difficult to express" proteins using their own standard protocols. One notable observation in the study is the very large differences between the different laboratories. There were many differences between the laboratories e.g. homologous recombination vs E.coli transposition based bacmid technology, cell lines, media, cell and virus concentrations at infection, time before harvest. There will also inevitably be differences that are more difficult to quantify. Because of the many differences it is not possible to definitively conclude that any particular system, cell line or method is better than another as the better performing labs use a range of different approaches. There is though a tentative suggestion that the transposition method (in particular EMBacY) may be more favourable due to the extra built in check points (e.g. blue/white colour selection and monitoring of virus production using the viral YFP marker). However this conclusion is only very tentative as it was clear that the recombination based method worked very well in one lab and in addition it is a simpler, quicker system. 


\section{Methods to improve the expression of difficult proteins Co-expression with chaperones}

Some proteins require molecular chaperones to assist in their correct intracellular folding into an active form. A multi-chaperone approach was developed by AB Vector [26] whereby five chaperone genes encoding Hsp90, Hsp40, Hsp70/Hsc70 and p23 were expressed simultaneously in a FoldHelper 905c recombinant baculovirus. This was shown to significantly increase both the overall yield and solubility of various steroid receptors. Co-infection with the recombinant Chaperone Bip virus has also been shown to increase the solubility and secretion of IgG in High Five cells especially after longer infection times (3.4 days) [27].

\section{Cold shocking}

For the first time a drop of temperature post infection to $19^{\circ} \mathrm{C}$ was shown to increase the yield and purity of the target protein, phosphatase PP2A, by over 3 -fold over 5 days. Interestingly, the PP2Ca protein was unaffected by this temperature shift [28].

\section{Co-expression with disulphide isomerases}

The protein disulphide isomerases, ERp57 and PDI, have been shown to facilitate correct disulphide bond formation and oxidative protein folding within the ER. Coinfection of insect cells with a recombinant virus containing these genes (termed FoldHelper-57P) along with the specific target protein recombinant virus promotes cysteine bond formation. Interestingly PDI also boosts protein production by delaying the cytopathic effect of virus infection [29].

\section{Addition of known protein ligands or inhibitors}

The expression of the catalytic domain of the serine/threonine kinase PKC $\theta$ was expressed mainly in a soluble form at $120 \mathrm{mg} /$ litre by the addition of the PKC inhibitor BIM XI to the culture media. Abl kinase protein expression could also be significantly increased by the addition of the inhibitor STI571 [30]. In general, complexing with ligands may increase protein production and performance by introducing conformational changes that effect overall protein stability [31].

\section{Blocking apoptosis}

Stably suppressing Bm-caspase-1 expression in High Five insect cells has been shown to significantly increase both intracellular and secreted recombinant protein production [32]. Overexpression of the already described anti-apoptotic protein Pvank-1 extends the protein production window by delaying apoptosis [11].

\section{Infected Insect cell metabolomics}

Extensive intracellular and extracellular metabolite profiling of $\mathrm{CHO}$ cells has been previously carried out to identify the limiting nutrients and bottlenecks in antibody 
production [33, 34]. Similar studies are very limited or absent with insect cell expression due to the shorter culture times involved of the baculoviral lytic process. However a detailed research review on the metabolite profiling of insect cells covering areas such as specific sugar utilisation, amino acid usage and lactate build up for biomanufacturing has been described [35].

\section{Troubleshooting}

It is essential to keep cells in the logarithmic phase of growth by regular passaging. Expressing a positive control protein such as GFP to monitor the health of your working cell stock as well as profiling target protein expression in two cell lines is highly recommended. There are many other reasons why expression can fail or succeed (choice of $\mathrm{N}$ or $\mathrm{C}$ terminal tagging, variable tags etc) but these are beyond the scope of this current review.

\section{Insect Cell Expression case examples}

Heparanase (HPSE1) enzyme cleaves heparan sulfate chains and has been shown to be a key player in angiogenesis and cancer progression [36, 37]. Significant amounts of the heterodimer enzyme were first produced (Figure 3) by secretion using High Five insect cells [38].

Heterodimer protein complexes can be produced by cloning both genes of interest directly into a dual expression plasmid or by co-infection of the individual recombinant viruses.

Another case study (Figure 4) shows two known membrane associated proteins that were cloned untagged into the pVL1392 vector and the active protein complex recovered from the microsome membrane fraction (Manchester Protein Expression Facility unpublished data).

A further example is shown in figure 5 of a cysteine and methionine rich glycoprotein that has been successfully secreted from High Five cells and purified using Ni affinity chromatography.

\section{Insect cell expression of membrane proteins}

\section{GPCR Protein production}

$\mathrm{G}$ protein coupled receptors (GPCRs) are part of a large family of seven transmembrane (7TM) spanning receptors and represent the most heavily investigated drug target class constituting 34\% of all FDA approved drugs acting on 108 unique GPCR proteins $[39,40]$. Over $70 \%$ of the known GPCR structures were solved using the baculovirus expression system with a 3-fold preference of Sf9 over High Five cells as the preferred host [10]. Some examples in the PDB database include the class B GPCR corticotrophin-releasing factor receptor 1 (PDB: 4K5Y), the long chain free fatty acid binding receptor GPR40 bound to agonist (PDB: 3SN6) and the b2adrenergic receptor (PDB 2RH1).

Alpha helical transmembrane anchors: 
The Full length Cytochrome P450 reductase enzyme ( $B d$ CPR) has been expressed in Sf9 cells using the Bac-to-bac system and the isolated membrane microsome fractions shown to have high cytochrome $\mathrm{C}$ reductase activity [41].

\section{Ion channels}

The Full length TRPV1 protein was expressed to a high level in High Five insect cells using a GP67 signal peptide secretory vector with C-terminal His tag. The GP67 signal peptide was shown to be critical for expression in both $\mathrm{Sf9}$ and High Five cells despite the fact that the protein was not secreted so presumably this helped in the initial membrane targeting of the protein to allow its assembly. The protein was shown to be active by whole cell ligand ion flux recordings and ligand binding studies [42].

\section{Conclusion}

Significant advances have taken place over the last 30 years with the development of engineered insect cell lines to cope with the increasing demand and complexity of recombinant protein production. The flashBAC innovation by OET that removed the need for plaque purification of recombinant viruses to select pure clones has made this a highly robust and fast method. The exciting development of the MultiBac system and rapid evolution of viral nanosystems has opened up the baculovirus system to address challenging multi protein complex production for the first time. The ability to co-express pathways of linked genes and other rate-limiting machinery without compromising the virus integrity has been a key leap in technology in the baculovirus research area.

\section{Methods for transient expression in mammalian cells}

\section{Introduction}

Transient expression of recombinant proteins in mammalian cells has traditionally suffered from very low yields in comparison to stable cell lines. Over the last approximately ten to fifteen years a number of developments have been described with transient systems, that enable the generation of tens to hundreds of milligram quantities of a wide range of proteins very rapidly [43-51). The process is very simple involving generation of plasmid, transfection in log phase, optional feeds from $24 \mathrm{~h}$ onwards and then harvest from $48 \mathrm{~h}$ to 14 days depending on the particular protein, cell line and conditions used.

The most important factors contributing to these developments have been firstly the development of cell lines that grow to high cell density in suspension culture, secondly combinations of recombinant cell lines and vectors that dramatically increase expression and thirdly, the development of transfection-compatible, chemically defined serum-free media and feed that allows transfection at higher cell density while prolonging cell culture viability. In addition a range of other culture parameters and additives have been analysed for their ability to boost expression of recombinant proteins. 


\section{Recombinant cell lines, vectors and media}

There are two cell lines that dominate in terms of their useage in this technology; human embryonic kidney 293 (HEK293) [see for example 43, 45 and 51] and chinese hamster ovary $(\mathrm{CHO})[42,43]$. Both have been adapted by multiple laboratories to grow in suspension which greatly facilitates the routine culture of the cells as well as being able to generate high cell densities to maximise expression on a per volume basis. Productivity from the two lines has been dramatically increased by the use of viral elements. Thus the cells are stably transfected with Epstein-Barr virus (EBV) nuclear antigen (EBNA-1) or SV40-T antigen and when used in conjunction with cisacting elements in a plasmid (EBV's oriP or SV40 ori) produce a large increase in expression. This is thought to enable episomal retention and replication of the plasmid and ultimately increased transcription and translation over a prolonged period of time $[43,52]$. However although many high yielding systems use these combinations of viral elements not all do so. Two studies describe a system that relies on a combination of cell line and transfection reagent to give efficient transfection combined with media and supplements that generate high cell densities [52, 53]. This is further discussed below.

Both $\mathrm{CHO}$ and HEK lines have been adapted to grow in chemically defined serum free medium that greatly facilitates purification of proteins when secreted in contrast to cells that have been grown in serum containing medium. A few examples of harvested culture supernatant are shown in Figure 6 and Figure 7 for a range of different proteins expressed in HEK and $\mathrm{CHO}$ cells respectively demonstrating the very low background of proteins compared to the recombinant protein even before any purification. Media are available from a number of suppliers including Thermo Fisher, Lonza, Irvine Scientific, GE Healthcare Life Sciences and Xell amongst others. Additionally various processes describe the addition of feeds post transfection that prolongs cell growth and viability and thereby further increases expression of recombinant protein $[45,53,54]$. A metabalomics approach was taken to understand nutrient limitations and subsequent addition of three amino acids, glucose and pyruvate led to a doubling of titre [33].

\section{Other Parameters to consider to improve yields}

In addition to cell lines, vectors and media a number of other factors are important in the success of the overall process. A variety of different transfection reagents have been reported although the most common is polyethyleneimine (PEI) due to its low cost and ease of use when purchased as a hydrochloride salt for example PEI MAX. It can also be ordered from Polysciences and Polyplus-transfection SA in various formulations. The transfection reagent:DNA complex can be preformed and then added to the cells or simply added separately and the complex allowed to form in the culture [55-57] an approach that greatly simplifies transfection automation. Transfection of cells can also be achieved by electroporation which can be performed at scale although the costs for equipment are high [58]. Although routine cell culture of HEK and $\mathrm{CHO}$ cells is performed at $37^{\circ} \mathrm{C}$ the temperature is frequently reduced post transfection to $30-34^{\circ} \mathrm{C}$. This is particularly effective with $\mathrm{CHO}$ cells [44, 59-61] although it has also been reported with HEK cells [60]. The reduced temperature 
slows down cell growth and prolongs cell viability whilst protein production continues. Other variables that have been observed to increase expression are the addition of chemicals particularly sodium valproate and butyrate [55] and cotransfection of other genes ( e.g. FGF) [55] with a mechanism that is unclear. Chaperones have been shown to improve expression when co-expressed [63]. It is often necessary to optimise a particular system especially with respect to cell density at transfection, the ratio of transfection agent to DNA and the concentration of DNA. This is most simply performed using a statistical Design of Experiment (DoE) approach to evaluate a number of parameters at the same time [57].

\section{Difficult to Express Proteins}

Many reports on different expression systems in the literature use proteins such as antibodies, Fc fusions or cytokines that are often straightforward to express. However the range of proteins that many laboratories need to express is far more diverse than this and a common occurrence is that expression levels can be very low $(<100 \mu \mathrm{g} / \mathrm{L})$ or not detectable at all. Under these circumstances it is essential to validate the cells and methods at the same time using a protein known to express well. Resolving this type of problem is probably one of the most time consuming and frustrating tasks in a protein expression and purification laboratory with no simple generically applicable solution. It is frequently necessary to manipulate the transfection and cell culture conditions, the methods for purification, the design of the expression plasmid and the sequence of the protein itself. This type of problem can occur even with related proteins [64]. If the quantities required are small it can be possible to generate a purified protein by scaling a process up. However this can be expensive and in some cases impossible.

Why does this huge variation in expression occur? A recent report [64] explored the reasons for these variations and some potential solutions by studying a group of structurally related proteins, the tissue inhibitors of metalloproteinases (TIMPs). They were able to demonstrate that it was not a problem of transcription or translation but rather there was a post translation block with the protein being retained in the ER. This could be overcome in part by engineering the protein to include a furin cleavable Pro sequence. This study provides some very useful answers at least in part to the problems of difficult to express proteins. However it still leaves open the question as to why one protein is retained in the ER whereas a structurally related protein readily transits through the secretory pathway.

\section{Mammalian Expression Systems}

There are many systems described in the literature and key elements of these have been discussed already. However many of these are proprietary and not available. The Expi293 and ExpiCHO systems are available from ThermoFisher who also sell a number of different suspension adapted HEK and $\mathrm{CHO}$ cell lines that grow in serum free medium. The National Research Council Canada license HEK293-6E and CHO systems that incorporate many of the benefits described above and also grow serum free in suspension.

\section{Expression of membrane proteins in mammalian cells}


A number of recent reviews have discussed different approaches to expressing membrane proteins in mammalian cells [65-68]. HEK lines are often used but other cell types are also discussed. Other approaches mentioned are different methods to introduce the gene into the cell including chemical transfection, infection with viruses such as Semliki Forest virus and adenoviruses and transduction with BacMam particles. A very common approach is to screen a large number of constructs by making a C-terminal fusion with a fluorescent protein such as GFP and then analyse expression level and monodispersity after solubilisation using analytical fluorescent size exclusion chromatography (FSEC). Once a suitable construct has been identified it can be switched to a different vector without the GFP tag and if necessary subcloned into a vector with an inducible promoter. In some cases the GFP can be retained without significant change to pharmacology [69]. A recent publication describes a system that generates stable pools of cells within 3 weeks and uses a cumate inducible switch to turn on expression [70]. This has shown some encouraging early data compared to transients on different types of membrane proteins including GPCRs and single pass membrane proteins (Yves DuRocher personal communication). Three recent examples of membrane protein expression in mammalian cells are described briefly below.

Lu et al [71] describe the cryoEM structure of a heterotrimeric NMDA receptor. The three sub-units of the receptor were expressed in a HEK cell line deficient in a Nacetyl-glucosaminyl transferase 1 thereby lacking complex $\mathrm{N}$-linked glycosyl structures. They were expressed using BacMam baculovirus mediated transduction. It is worth noting that the proteins had to be extensively engineered and required the presence of two different Fab fragments to facilitate the cryoEM study.

A further landmark study was published last year on the crystal structure of the excitatory amino acid transporter 1 (EAAT1), a member of the solute carrier 1 family of transporters (SLC1) [72]. This also required significant engineering of the WT protein in order to make it more thermostable. Both solubilisation conditions and a large number of mutants were screened using FSEC utilising eGFP fused to the Cterminus of the constructs. In addition N-linked glycosylation sites were removed. The protein was expressed in suspension HEK293F cells and purified primarily using a Strep-tag II and a Streptactin affinity resin.

A third example described the use of surface plasmon resonance (SPR) to screen fragment libraries [73]. There is very little detail on the expression in this study but mammalian cells were used to express GPCRs which were immobilised on the surface of a sensor chip using a C9 peptide tag fused to the protein and the 1D4 monoclonal antibody. The immobilised receptors were then used to screen the fragment libraries. In this example the WT receptor was used rather than engineered stable variants as the phamacology towards agonists and antagonists is likely to be more similar to the membrane bound protein. Clearly the authors then needed to overcome issues of stability once the protein was extracted from the membrane using detergent.

\section{A comparison of insect and mammalian expression systems}


Some of the different aspects of the two systems, both scientific and practical, are compared in Table 1. Both systems are eukaryotic expression systems and as such are applicable to many eukaryotic proteins because of their ability to perform a wide range of post-translational modifications. Possibly the most notable difference is that N-linked glycosylation in insect cells is much simpler, restricted to small high mannose structures unless the cell has been modified with additional enzymes to create mammalian type structures (SweetBac). What is of far greater importance is the design of the protein and expression approach. Thus for example if the protein is normally found in the extracellular environment it should generally be secreted with a signal peptide, if it exists in a complex, consideration should be given to coexpression with these partners.

There are some practical dfferences. Transient expression in mammalian cells is very quick and can give expression as high or even higher than with insect cells especially for secreted proteins. However it is more expensive due to more expensive culture media and the choice of systems is much more limited and often requires a license. Furthermore suspension mammalian cell culture requires shaking $\mathrm{CO} 2$ incubators that are an additional expense.

\section{Highlights}

- Higher eukaryotic expression systems are often the preferred choice for complex proteins requiring post translational modification including folding.

- The most frequently used systems are baculovirus infected insect cells and HEK or CHO mammalian cells.

- Despite their obvious advantage over microbial hosts there are often still problematic proteins that require significant effort to overcome the difficulties.

- Membrane proteins perhaps represent the greatest challenge but significant progress has been made to devise methods to express, purify and then use these membrane proteins to facilitate structural biology and approaches to discover new therapeutic agents.

\section{Acknowledgements}

Thanks to Dr Mark Elvin, Professor Alan Dickson and Professor Yves Durocher for valuable feedback. Thanks to Dr Claire Gaffney for helping prepare the figures. Thanks also to Matthew Ball, Jack Said and Dr Ruth Lopez for proof reading this review.

\section{References}

1. G.E. Smith, M.D. Summers \& M.J. Fraser. Production of human beta interferon in insect cells infected with a baculovirus expression vector. Mol Cell Biol. 12 (1083) 2156-65.

2. M.M. Van Oers, G.P. Pijlman \& J.M. Vlak. Thirty years of baculovirusinsect cell protein expression: from dark horse to mainstream technology. $J$ Gen Virol. 96(Pt 1) (2015) 6-23.

3. H. Jorio, R. Tran \& A. Kamen. Stability of serum-free and purified baculovirus stocks under various storage conditions. Biotechnol Prog. 22 (1) (2006) 319-25. 
4. A. Roldao, R. Oliveira, M.J. Carrondo \& P.M. Alves. Error assessment in recombinant baculovirus titration: evaluation of different methods. J. Virol. Methods. 159 (2009) 69-80.

5. Y. Hashimoto, S. Zhang \& G.W. Blissard . Ao38, a new cell line from eggs of the black witch moth, Ascalapha odorata (Lepidoptera: Noctuidae), is permissive for AcMNPV infection and produces high levels of recombinant proteins. BMC Biotechnol. 10:50 (2010) 1186-1202.

6. J.J. Aumiller, H. Mabashi-Asazuma, A. Hillar, X. Shi \& D.L. Jarvis. A new glycoengineered insect cell line with an inducibly mammalianized protein Nglycosylation pathway. Glycobiology. 3 (2012) 417-28.

7. D.E. Lynn. Baculovirus and Insect Cell Expression Protocols, 2e. Methods in Molecular Biology 338 (6) 117-137.

8. M. Martínez-Solís, S. Gómez-Sebastián, J.M. Escribano, A.K. Jakubowska \& S.A. Herrero. A novel baculovirus-derived promoter with high activity in the baculovirus expression system. PeerJ. 4 (2016) e2183.

9. R.D. Possee, R.B. Hitchman, K.S. Richards, S.G. Mann, E. Siaterli, C.P. Nixon, H. Irving, R. Assenberg, D. Alderton, R.J. Owens \& L.A. King. Generation of baculovirus vectors for the high throughput production of proteins in insect cells. Biotechnol Bioeng. 101 (6) (2008) 1115-1122.

10. T. Saarenpää, V.P. Jaakola \& A. Goldman. Baculovirus-mediated expression of GPCRs in insect cells. Methods Enzymol. 556 (2015) 185-218.

11. K.H. Steele, B.J. Stone, K.M. Franklin, A. Fath-Goodin, X. Zhang, H. Jiang, B.A. Webb \& C. Geisler. Improving the baculovirus expression vector system with vankyrin-enhanced technology. Biotechnol Prog. 33 (6) (2017) 1496-1507.

12. T. Meng, A.B. Kolpe, T.K. Kiener, V.T. Chow \& J. Kwang. Display of VP1 on the surface of baculovirus and its immunogenicity against heterologous human enterovirus 71 strains in mice. PLoS One. 6(7) (2011) e21757.

13. K.M. Lindley, J.L. Su, P.K. Hodges, G.B. Wisely, R.K. Bledsoe, J.P. Condreay, D.A. Winegar, J.T. Hutchins \& T.A. Kost. Production of monoclonal antibodies using recombinant baculovirus displaying gp64-fusion proteins. J Immunol Methods. 234 (2000) 123-35.

14. Oxford Expression Technologies (OET) website accessed $11^{\text {th }}$ Jan 2018 https://oetltd.com/

15. Y. Zhao, D.A. Chapman and I.M. Jones. Improving baculovirus recombination. Nucleic Acids Res. (2003) Jan 15; 31(2):E6-6

16. ThermoFisher Scientific web site accessed $11^{\text {th }}$ Jan 2018.https://www.thermofisher.com/uk/en/home/life-science/proteinbiology/protein-expression/insect-protein-expression/bac-to-bac-baculovirusexpression-system.html

17. J.L. Mehalko \& D. Esposito. Engineering the transposition-based baculovirus expression vector system for higher efficiency protein production from insect cells. J Biotechnol. 238 (2016) 1-8.

18. I. Berger \& A. Poterszman. Baculovirus expression: old dog, new tricks. Bioengineered. 6(6) (2015) 316-22.

19. Geneva Biotech web site accessed $11^{\text {th }}$ Jan 2018. http://genevabiotech.com/product_category/insect-cell-expression/multibac/

20. M. Pelosse, H. Crocker, B. Gorda, P. Lemaire, J. Rauch \& I. Berger. MultiBac: from protein complex structures to synthetic viral nanosystems. BMC Biol. 15(1) (2017) 99. 
21. D. Palmberger, M. Klausberger, I. Berger \& R. Grabherr. MultiBac turns sweet. Bioengineered. 4(2) (2013)78-83.

22. Y. Shang, M. Wang, G. Xiao, X. Wang, D. Hou, K. Pan, S. Liu, J. Li, J. Wang, B.M. Arif, J.M. Vlak, X. Chen, H. Wang, F. Deng \& Z. Hu. Construction and Rescue of a Functional Synthetic Baculovirus. ACS Synth Biol. 6(7) (2017)1393-1402.

23. K.H. Loomis, K.W. Yaeger, M.M. Batenjany, M.M. Mehler, A.C. Grabski, S.C. Wong \& R.E. Novy. InsectDirect System: rapid, high-level protein expression and purification from insect cells. J Struct Funct Genomics. 6(2-3) (2005) 189-94.

24. A.M. Moraes, S.A. Jorge, R.M. Astray, C.A. Suazo, C.E. Calderón Riquelme, E.F. Augusto, A. Tonso, M.M. Pamboukian, R.A. Piccoli, M.F. Barral \& C.A. Pereira. Drosophila melanogaster S2 cells for expression of heterologous genes: From gene cloning to bioprocess development. Biotechnol Adv. 30 (3) (2012) 613-28.

25. P.Stolt-Bergner, C. Benda, T. Bergbrede, H. Besir, P.H.N Celie, C. Chang, D. Dreschsel, A. Fischer, A. Geerlof, B. Giabbai, J. van den Heuvel, G. Huber, W. Knecht, A. Lehner, R. Lemaitre, K. Norden, G. Pardee, I. Racke, K. Remans, A. Sander, J. Scholz, M. Stadnik, P. Storici, D. Weinbruch, I. Zaror, L.H.L Lua \& S. Suppmann. Baculovirus-driven protein expression in insect cells: A benchmarking study. J Struct Biol. (2018) S1047-8477(18) 30066-2.

26. $\mathrm{AB}$ Vector web site accessed $11^{\text {th }}$ Jan 2018. http://www.abvector.com/index.htm

27. T.A. Hsu \& M.J. Betenbaugh. Coexpression of molecular chaperone BiP improves immunoglobulin solubility and IgG secretion from Trichoplusia ni insect cells. Biotechnol Prog. 13(1) (1997) 96-104.

28. T. Ikehara, S. Nakashima, J. Nakashima, T. Kinoshita \& T. Yasumoto. Efficient production of recombinant PP2A at a low temperature using a baculovirus expression system. Biotechnol Rep (Amst). 11 (2016) 86-89.

29. K. Kitchin \& M.C. Flickinger. Alteration of hybridoma viability and antibody secretion in transfectomas with inducible overexpression of protein disulfide isomerase. Biotechnol Prog. 11(5) (1995) 565-74.

30. A. Strauss, G. Fendrich, M.A. Horisberger, J. Liebetanz, B. Meyhack, J.M. Schlaeppi \& R. Schmitz. Improved expression of kinases in Baculovirusinfected insect cells upon addition of specific kinase inhibitors to the culture helpful for structural studies. Protein Expr Purif. 56(2) (2007) 167-76.

31. M.S. Celej, G.G. Montich \& G.D. Fidelio. Protein stability induced by ligand binding correlates with changes in protein flexibility. Protein Sci. 12 (7) (2003) 1496-1506.

32. Q. Wang, Y. Zhou, K. Chen, X. Ju. Suppression of Bm-Caspase-1 Expression in BmN Cells Enhances Recombinant Protein Production in a Baculovirus Expression Vector System. Mol Biotechnol. 58(5) (2016) 319-27.

33. C.A. Sellick, A.S. Croxford, A.R. Maqsood, G. Stephens, H.V. Westerhoff, R. Goodacre \& A.J. Dickson. Metabolite profiling of recombinant CHO cells: designing tailored feeding regimes that enhance recombinant antibody production. Biotechnol Bioeng. 108 (12) (2011) 3025-31.

34. C.A. Sellick, A.S. Croxford, A.R. Maqsood, G.M. Stephens, H.V. Westerhoff, R. Goodacre \& A.J. Dickson. Metabolite profiling of CHO cells: Molecular reflections of bioprocessing effectiveness. Biotechnol J. 10(9) (2015) 1434-45. 
35. J.C. Drugmand, Y.J. Schneider \& S.N. Agathos. Insect cells as factories for biomanufacturing. Biotechnol Adv. 30(5) (2012)1140-57.

36. V. Masola, M.F. Secchi, G. Gambaro \& M. Onisto. Heparanase as a target in cancer therapy. Curr Cancer Drug Targets. 14(3) (2014) 286-93.

37. I. Vlodavsky, M. Gross-Cohen, M. Weissmann, N. Ilan \& R.D. Sanderson. Opposing Functions of Heparanase-1 and Heparanase-2 in Cancer Progression. Trends Biochem Sci. 43(1) (2018)18-31.

38. E. McKenzie, K. Young, M. Hircock, J. Bennett, M. Bhaman, R. Felix, P. Turner, A, Stamps, D. McMillan, G. Saville, S. Ng, S. Mason, D. Snell, D. Schofield, H. Gong, R. Townsend, J. Gallagher, M. Page, R. Parekh \& C. Stubberfield. Biochemical characterization of the active heterodimer form of human heparanase (Hpa1) protein expressed in insect cells. Biochem J. 373(Pt 2) (2003) 423-35.

39. V.A. Villar, S. Cuevas, X. Zheng \& P.A. Jose. Localization and signaling of GPCRs in lipid rafts. Methods Cell Biol. 132 (2016) 3-23.

40. A.S. Hauser, M.M. Attwood, M. Rask-Andersen, H.B. Schiöth \& D.E. Gloriam. Trends in GPCR drug discovery: new agents, targets and indications. Nat Rev Drug Discov. 12 (2017) 829-842.

41. X.P. Huang Lu, L.L. Wang, D. Weie, Z.J. Feng, Q. Zhang, L.F. Xiao, W. Dou \& J.J. Wang. Functional characterization of NADPH-cytochrome P450 reductase fromBactrocera dorsalis: Possible involvement in susceptibility to malathion. Scientific Reports 5 (2015) 18394.

42. A. Korepanova, A. Pereda-Lopez, L.R. Solomon, K.A. Walter, M.R. Lake, B.R. Bianchi, H.A. McDonald, T.R. Neelands, J. Shen, E.D. Matayoshi, R.B. Moreland \& M.L. Chiu. Expression and purification of human TRPV1 in baculovirus-infected insect cells for structural studies. Protein Expr Purif. 65(1) (2009) 38-50.

43. Y. Durocher, S. Perret, S. Kamen, High-level and high-throughput recombinant protein production by transient transfection of suspensiongrowing human 293-EBNA1 cells, Nucleic Acids Res. 15 (2002) Jan 30(2):E9.

44. J. Y. Baik, M.S. Lee, S.R. An, S.K. Yoon, E.J. Joo, Y.H. Kim, H.W. Park, G.M. Lee, Initial transcriptome and proteome analyses of low culture temperature-induced expression in $\mathrm{CHO}$ cells producing erythropoietin, Biotechnology and bioengineering, 93 (2006) 361-371.

45. P.L. Pham, A. Kamen, Y. Durocher, Large-scale transfection of mammalian cells for the fast production of recombinant protein, Molecular biotechnology, 34 (2006) 225-237.

46. L. Baldi, D.L. Hacker, M. Adam, F.M. Wurm, Recombinant protein production by large-scale transient gene expression in mammalian cells: state of the art and future perspectives. Biotechnology Letters, 29 (2007) 677-684.

47. S. Geisse, Reflections on more than 10 years of TGE approaches. Protein expression and purification, 64 (2009) 99-107.

48. J.E. Nettleship, R. Assenberg, J.M. Diprose, N. Rahman-Huq, R.J. Owens, J.E. Nettleship, Recent advances in the production of proteins in insect and mammalian cells for structural biology, J. Struct. Biol. 172 (2010) 55-65.

49. S. Geisse, B. Voedisch, Transient expression technologies: past, present, and future, Methods in molecular biology (Clifton, N.J.), 899 (2012) 203-219.

50. D.L. Hacker, D. Kiseljak, Y. Rajendra, S. Thurnheer, L. Baldi, F.M. Wurm, Polyethyleneimine-based transient gene expression processes for suspension- 
adapted HEK-293E and CHO-DG44 cells. Protein Expression and Purification, 92 (2013) 67-76.

51. H.C. Chiou, S Vasu, C.Y. Liu, I Cisceros, M.B. Jones, J.F. Zmuda, Scalable transient protein expression, Methods Mol. Biol. 1104 (2014) 35-55.

52. K. Van Craenenbroeck, $P$ Vanhoenacker, G Haegeman, Episomal vectorsfor gene expression in mammalian cells, Eur. J. Biochem. 267 (2000) 5665-5678.

53. N.K. Jain, S. Barkowski-Clark, R. Altman, K. Johnson, F. Sun, J. Zmuda, C.Y.Liu, A.Kita, R. Schulz, A. Neill, R. Ballinger, R. Patel, J. Liu, A. Mpanda, B. Huta, H. Chiou, W. Voegtli, T. Panavas. Protein Expression and Purification, 134 (2013) 38-46.

54. O. Daramola, J. Stevenson, G. Dean, D. Hatton, G. Pettman, W. Holmes, R. Field, A high-yielding $\mathrm{CHO}$ transient system: coexpression of genes encoding EBNA-1 and GS enhances transient protein expression, 2014. Biotechnology progress, 30 (2014) 132-141.

55. G. Backliwal, M.Hildinger, V. Hasija, F. Wurm, High-density transfection with HEK-293 cells allows doubling of transient titers and removes need for a priori DNA complex formation with PEI, Biotechnology and bioengineering, 99 (2008) 721-727.

56. C. Raymond, R. Tom, S. Perret, P. Moussouami, D. L'Abbe, Y. Durocher, A simplified polyethylenimine-mediated transfection process for large-scale and high-throughput applications, Methods (San Diego, Calif.), 55 (2011) 44-51.

57. W.M. Abbott, B. Middleton, F. Kartberg, J. Claesson, R. Roth, D.Fisher, Protein Expression and Purification, 12 (2015) 113-119.

58. K. Steger, J. Brady, W. Wang, M Duskin, K. Donato, M. Peshwa, J. Biomol. Screening, 20 (2015) 545-551.

59. S. Wuhlfard, S. Tissot, S. Bouchet, J. Cevey, M. DeJesus, D.L. Hacker, F. Wurm, Mild hypothermia improves transient gene expression yields several fold in Chinese hamster ovary cells, Biotechnology progress, 24 (2008) 458465.

60. Y. Rajendra, D. Kiseljak, L. Baldi, D.L. Hacker, F.M. Wurm, A simple highyielding process for transient gene expression in CHO cells, 2011. Journal of Biotechnology, 153 (2011) 22-26.

61. N.F. Macaraeg, D.E. Reilly, A.W. Wong, Use of an anti-apoptotic CHO cell line for transient gene expression, Biotechnology progress, 29 (2013) 10501058.

62. C-Y. Lin, Z Huang, W. Wen, A Wu, C. Wang, L. Niu, Enhancing Protein Expression in HEK-293 cells by lowering culture temperature, PLOS One, 10 (2015) e0123562

63. K. Cain, S. Peters, H. Hailu, B. Sweeney, P. Stephens, J. Heads, K. Sarkar, A. Ventom, C. Page, A. Dickson, A CHO cell line engineered to express XBP1 and ERO1-Lalpha has increased levels of transient protein expression, Biotechnology progress, 29 (2013) 697-706.

64. H Hussain, D.I Fisher, W.M. Abbott, R.G. Roth, A.J. Dickson, Use of a protein engineering strategy to overcome limitations in the production of "Difficult to Express" recombinant proteins. Biotechnology and bioengineering, 114 (2017) 2348-2359.

65. L.E. Bird, J.E. Nettleship, V. Jarvinen, H. Rada, A. Verma, R Owens, Expression screening of integral membrane proteins by fusion to fluorescent reporters, Advances in Exp. Med. And Biology, 922 (2016) 1-11 
66. S. Chaudhary, J.E. Pak, B.P. Pedersen, L.J. Bang, L.B. Zhang, S.M.M. Ngaw, R.G. Green, V. Sharma, R.M. Stroud, Efficient expression screening of human membrane proteins in transiently transfected Human Embryonic KidneyS cells, Methods 55 (2011) 273-280

67. J. Andrell, C.G. Tate, Overexpression of membrane proteins in mammalian cells for structural studies, Molecular Membrane Biology 30 (2013) 52-63

68. A. Goehring, C-H. Lee, K.H. Wang, J.C. Michel, D.P. Claxton, I. Baconguis, T. Althoff, S. Fischer, K.C. Garcia, E. Gouaux, Screening and large scale expression of membrane proteins in mammalian cells for structural studies, Nature Protocols, 9 (2014) 2574-2585

69. C. Shi, Y-O. Shin, J. Hanson, B. Cass, M.C. Loewen, Y Durocher, Purification and characterisation of a recombinant G-protein-coupled receptor, Saccharomyces cerevisiae Ste2p, transiently expressed in HEK293 EBNA1 cells, Biochemistry, 44 (2005) 15705-15714

70. A. Poulain, S. Perret, F. Malenfant, A. Mullick, B. Massie, Y. Durocher, Rapid protein production from stable $\mathrm{CHO}$ cell pools using plasmid vector and the cumate gene-switch, J. of Biotechnology, 255 (2017) 16-27

71. W. Lu J. Du, A. Goehring, E. Gouaux, Cryo-EM structures of the triheterotrimeric NMDA receptor and its allosteric modulation, Science, 355 (2017) 6331

72. J.C. Canul-Tec, R. Assal, E. Cirri, P. Legrand, S. Brier, J. Chamot-Rooke, N. Reyes, Structure and allosteric inhibition of excitatory amino acid transporter 1. Nature 544 (2017) 446-451

73. C.A. Shepherd, A.L. Hopkins, I Navratilova, Fragment screening by SPR and advanced applications to GPCRs, Progress in Biophys. And Mo. Biol., 116 (2014) 113-123

\section{Figure Legends}

Figure1: Comparative workplan for recombinant baculovirus generation using the FlashBAC ${ }^{\mathrm{TM}}$ and MultiBac ${ }^{\mathrm{TM}}$ methods. The molecular differences between the FlashBAC ${ }^{\mathrm{TM}}$ recombination and MultiBac ${ }^{\mathrm{TM}}$ transposition based methods are shown. The approximate timelines for each method from cloning to protein production are depicted. The example shows the production of a His tagged mCherry red fluorescent control protein.

Figure 2: Stages of the insect cell infection cycle. The viral infection cycle of insect cells can be divided into distinct phases and promoters become activated at defined points. The schematic illustrates the typical cell morphology changes upon viral infection.

Figure 3: Secretion of HPSE1 heterodimer complex in High Five cells. The 8KDa regulatory subunit and 50KDa catalytic subunits of HPSE1 (i), were cloned into the dual expression plasmid pACUW51 with additional GP67 signal peptide fused to the N-terminus of each subunit (ii), High Five cells were transfected with the recombinant virus and heterodimer protein purified from the media by heparin affinity chromatography (iii), A minor degradation band (lane 1) could be removed by an additional ion exchange step (lane 2). 
Figure 4: Co-infection of recombinant viruses into High Five cells. Recombinant viruses expressing a membrane protein (A) and membrane associated protein (B) were generated and then titred. A range of multiplicities of infection were selected (i), Viruses were co-infected into High Five cells, left for $72 \mathrm{hrs}$ and then fractionated for Total and Soluble fractions (ii), Co-infection produced a membrane A:B complex and also excess of soluble unbound B protein (iii).

Figure5: Secretion of a cysteine/methionine rich, glycoprotein in High Five cells. The schematic (i) shows the key features of the protein including signal peptide, Histidine rich C-terminal tail (acting as an endogenous high affinity metal binding tag), glycosylation sites and abundance of Cysteine residues (36 amino acids forming 18 disulphide bonds). The codon optimised gene lacking the signal peptide was first cloned into the pACGP67 transfer plasmid. High Five cells were infected with FlashBAC ${ }^{\mathrm{TM}}$ generated recombinant virus (MOI of 5) and left for 3 days at $28 \mathrm{oC}$. Media was clarified then purified over a Nickel sepharose column, washed in a low stringency Imidazole gradient and then eluted in 250mM Imidazole (ii).

Figure 6. Expression of a range of different His and $\mathrm{Fc}$ tagged proteins in HEK293-6E cells. The samples are all culture supernatants harvested 5-6 days after transfection and before any purification. M, molecular weight markers; lanes 1-3, three variants of $6 \mathrm{His}$ tagged TIMP 2 expressing at $\sim 20 \mathrm{mg} / \mathrm{L}$; lanes 4,6 and 7 a single imuunoglobulin domain containing receptor fused at the C-terminus with Fc; expression level was $\sim 100 \mathrm{mg} / \mathrm{L}$; lane 5 is the same immunoglobulin domain containing protein without a tag expressed at $\sim 20 \mathrm{mg} / \mathrm{L}$; lane 8 is a 6 His tagged secreted protease with expression at $50-100 \mu \mathrm{g} / \mathrm{L}$ and was undetectable prior to $\mathrm{Ni}$ purification. Expression levels were determined after purification using one or two chromatographic steps.

Figure 7. Expression of different proteins in CHO suspension cells. $50 \mathrm{ml}$ of cells was transfected in situ, fed with 33ml Tryptone N1 in CD CHO 24 hours posttransfection, cells transferred to $30^{\circ} \mathrm{C} 3$ days post-transfection and harvested 14 days post-transfection. 5A. SDS-PAGE analysis of culture supernatants. 5B. SDS-PAGE analysis after purification on Ni column using PhyNexus MEA workstation. R) RON(ECD); C) CD80; A) ALK1-Fc; B) BAFFR-Fc; I) IL-17A; P) mPAI-1. From [57] 

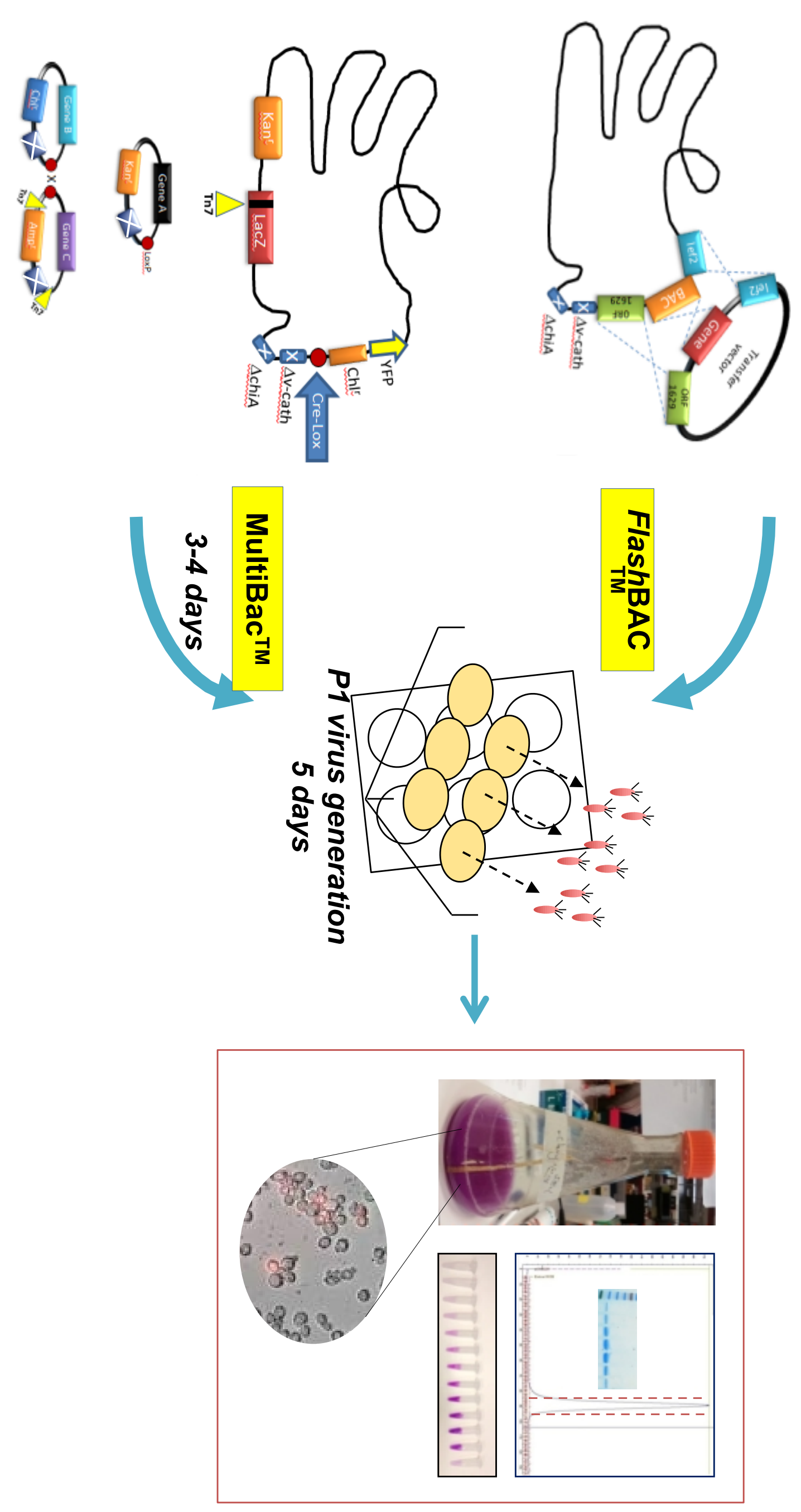


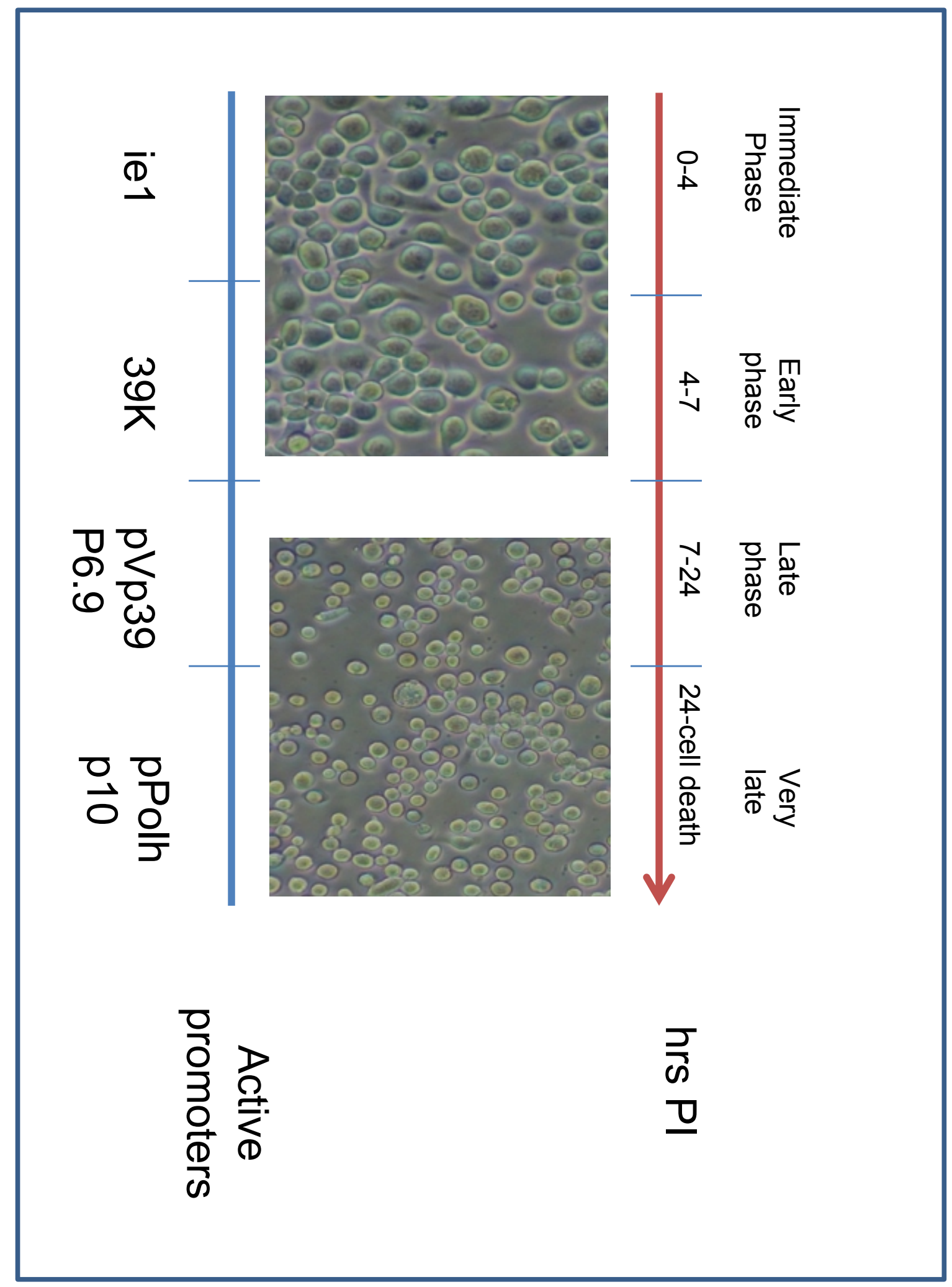



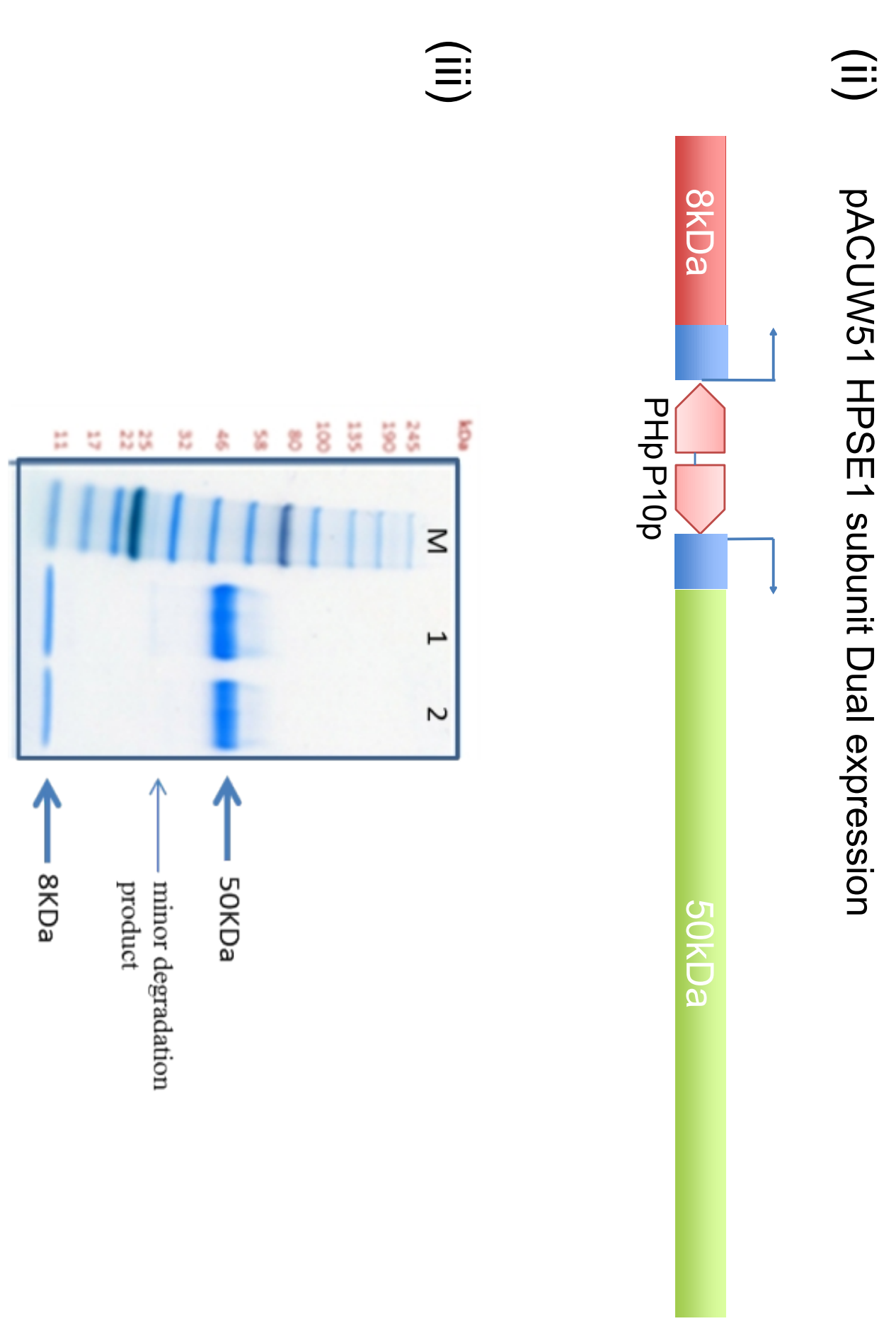

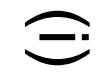

$\widehat{\equiv}$

ङ
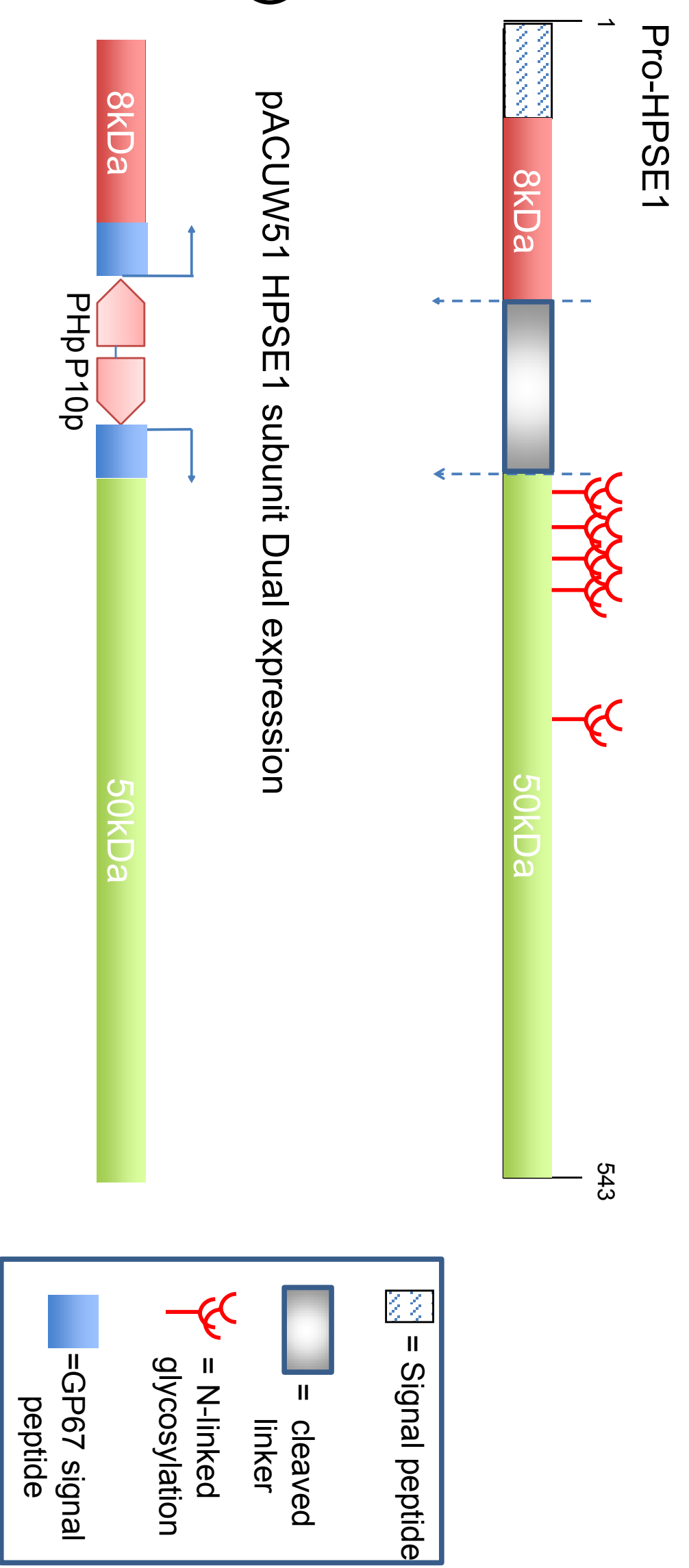


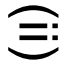

$\lesssim$

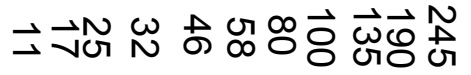

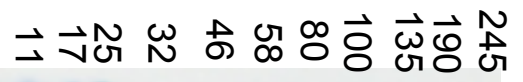
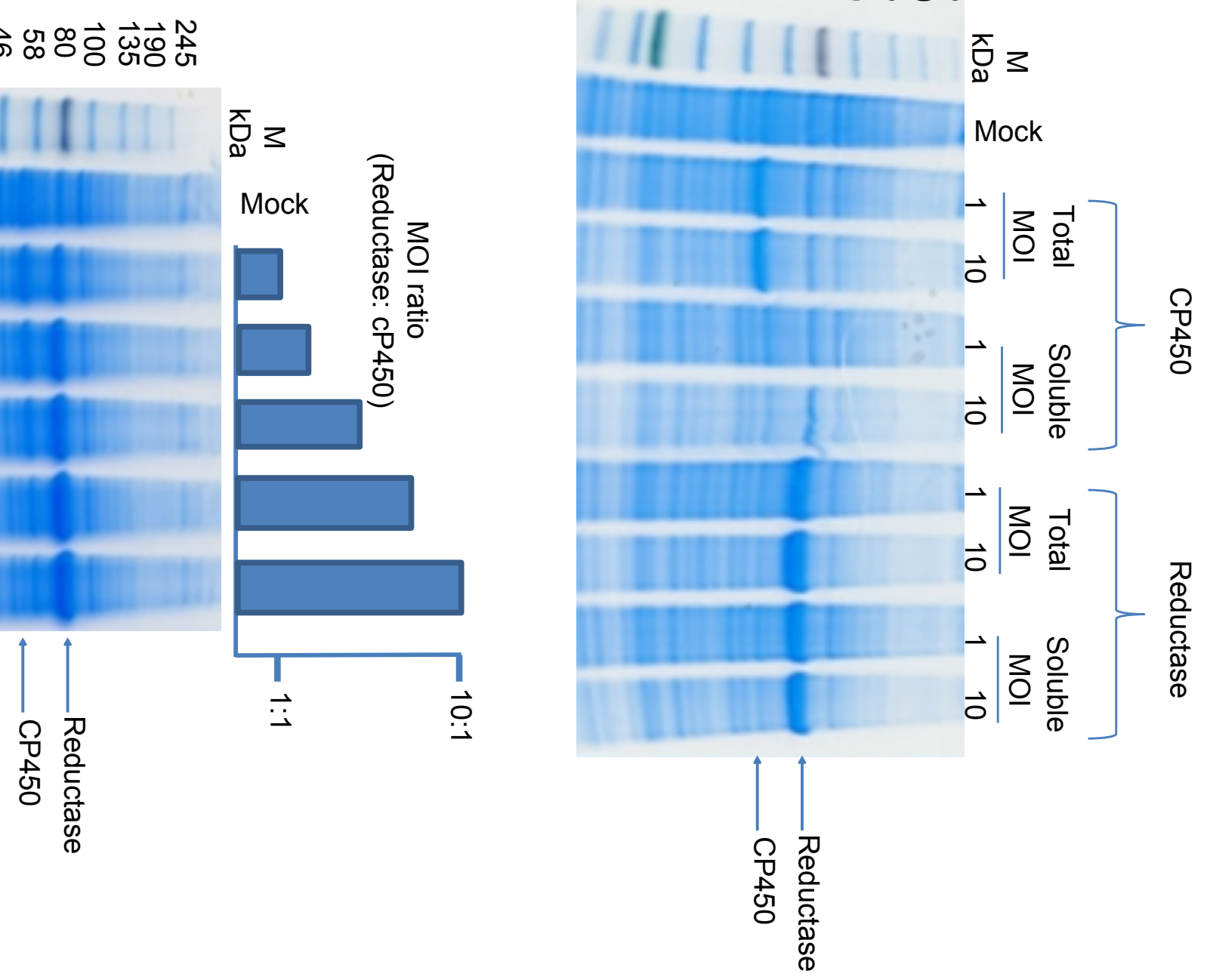

છ

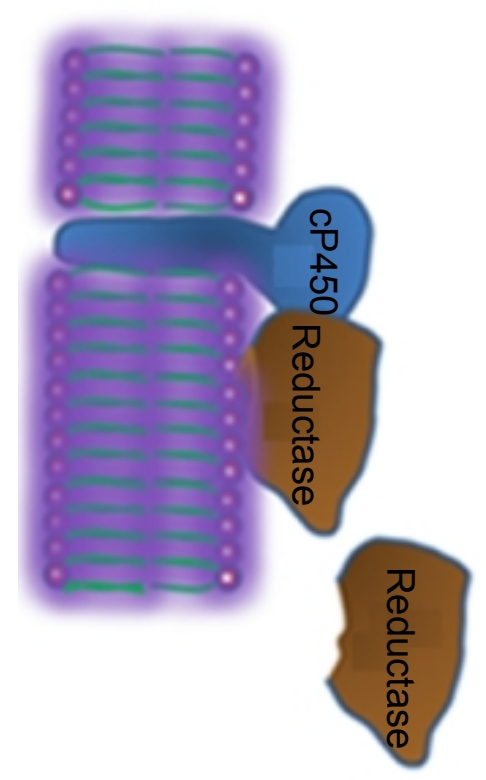


ミ

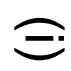

$\overrightarrow{~ ज N ~}$ ज O

Conditioned media

Flow through
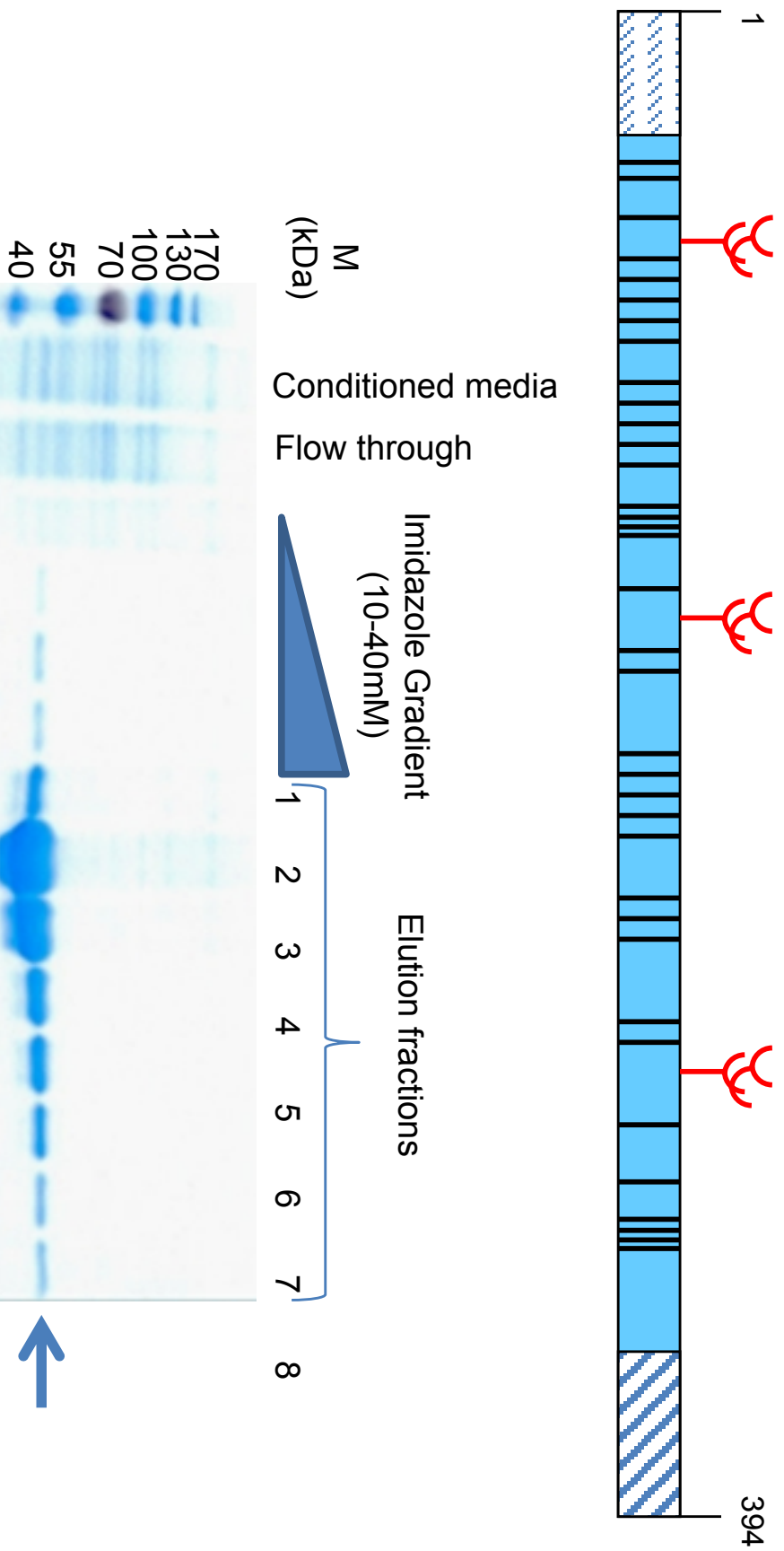

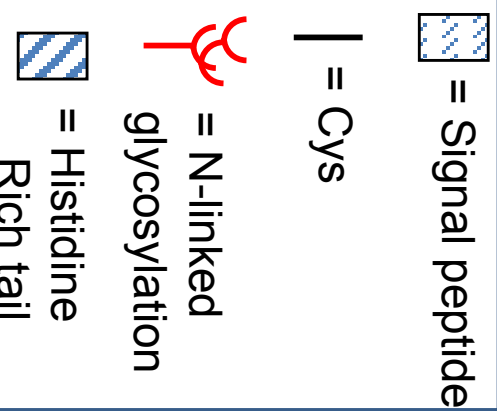




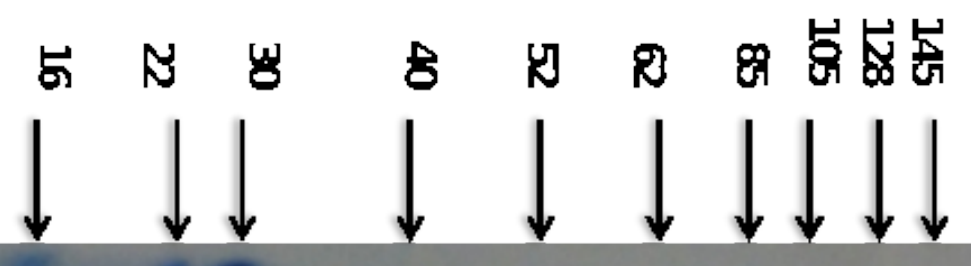

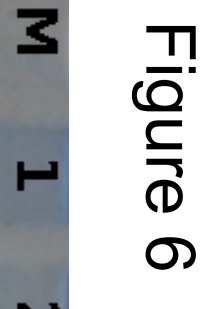

N

$\omega$

$+$

기

o)

$\infty$ 


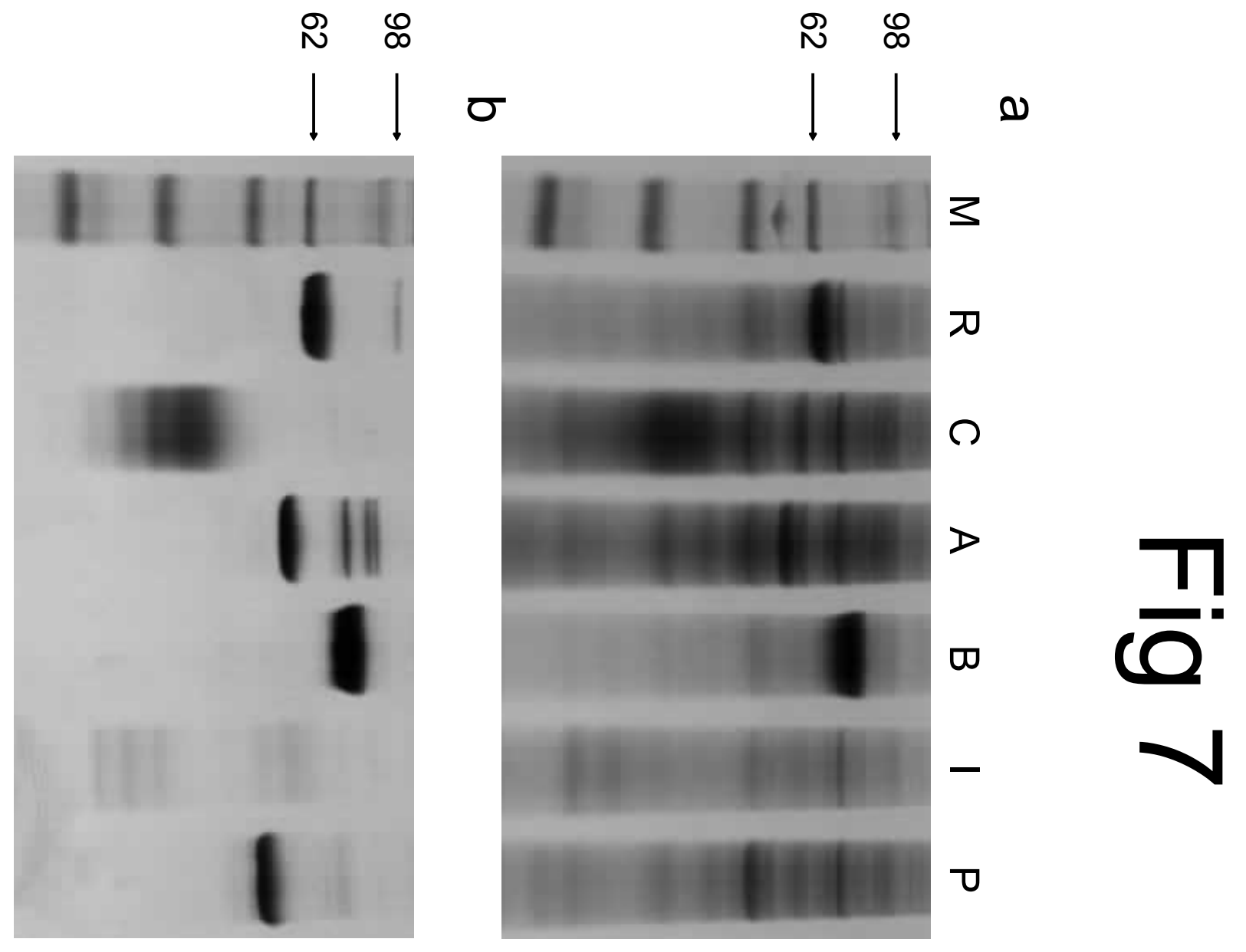




\section{$\frac{\vec{\partial}}{\frac{\partial}{\sigma}}$}

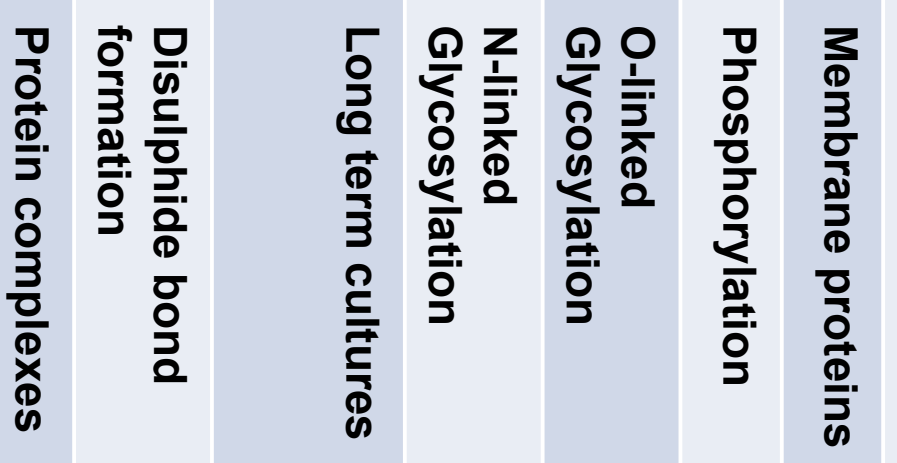

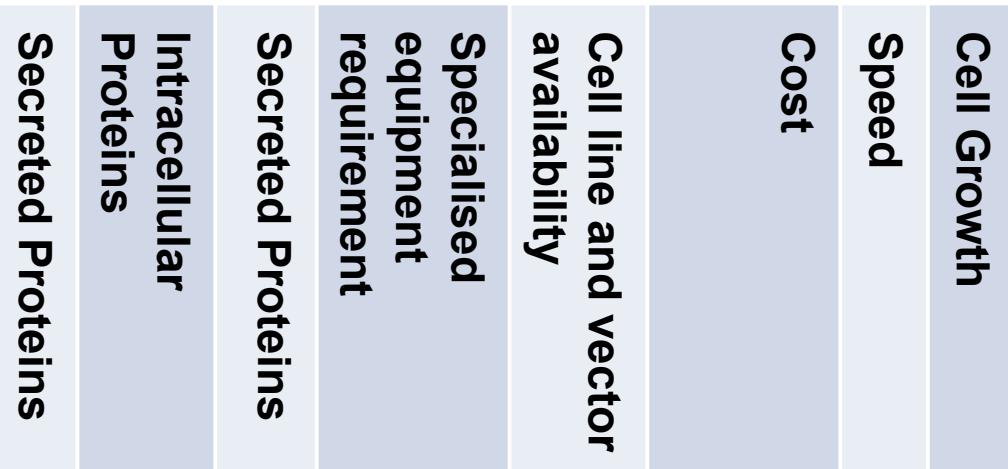

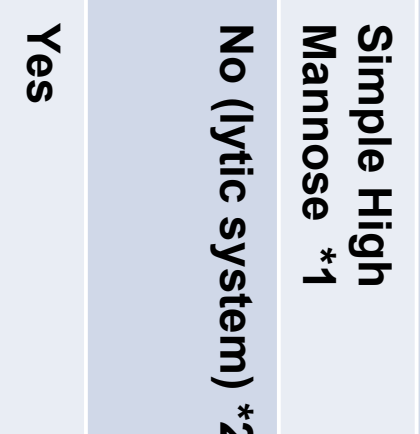

๙

กิำ

䓂

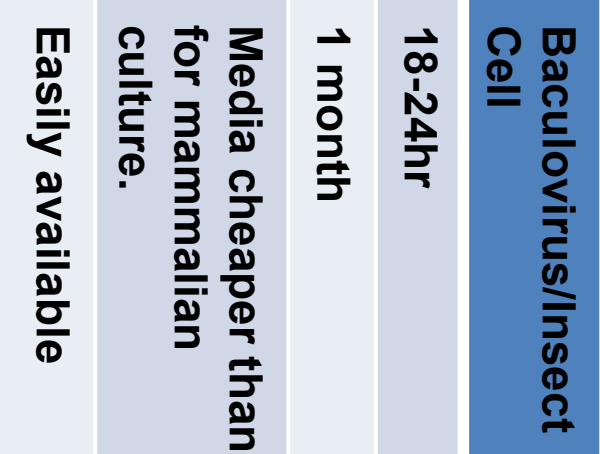

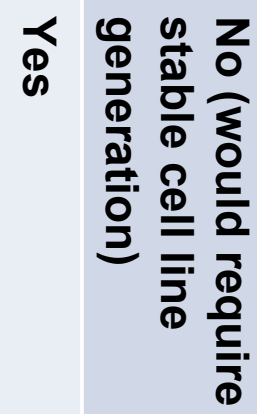

怘

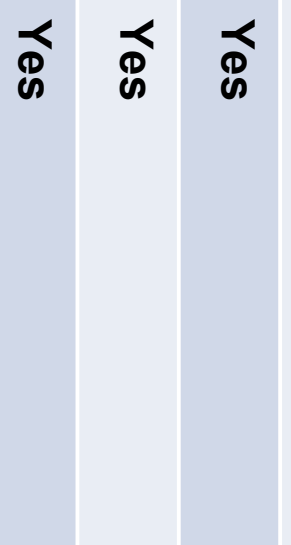

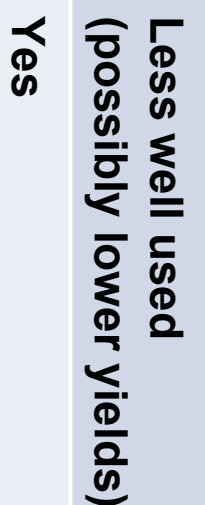

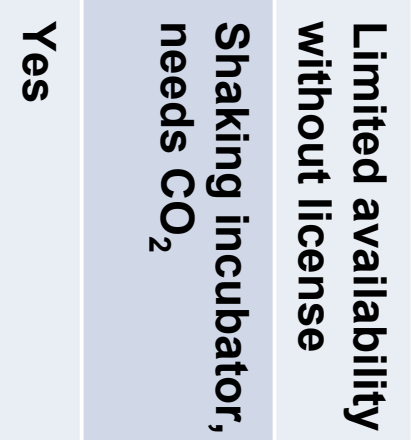
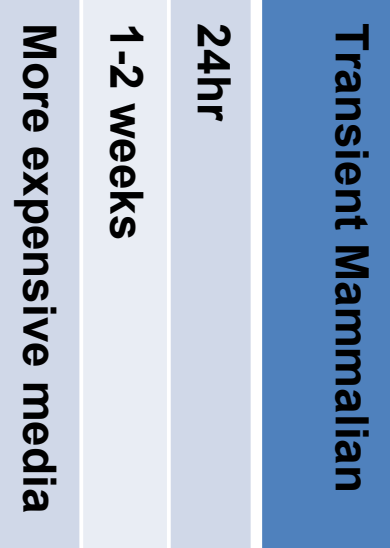

ผै 节 ํํำ

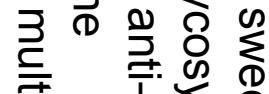

ญे

응 훙 융

ㅎํ용

ㅎํ응

के टे

ฏ)

잠

을

은

을 商

을. 